\title{
RAKENDUSLINGVISTIKA EPISTEMOLOOGILISEST STAATUSEST
}

\author{
KARLFRIED KNAPP
}

\section{Sissejuhatus: rakenduslingvistika - kas akadeemiline distsipliin?}

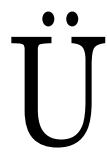
ha kasvava poliitilise ja majandusliku surve all ei ole akadeemilistel erialadel enam võimalik mööda vaadata neid toitva ühiskonna praktilistest probleemidest. Enamgi veel: nad ei tohi piirduda probleemide pelga kirjelduse või tõlgendusega. Nüüdisajal oodatakse üha kärsitumalt, et kõik akadeemilised erialad õigustaksid neile eraldatud toetust ning nihutaksid fookuse probleemi mõ is tmiselt probleemi lahendamisele.

See käib ka lingvistika kohta. Lingvistika uurib keelekasutuse struktuure ja viise eesmärgiga seletada keele vormi ja kasutusega seotud seaduspärasusi ja suhteid, kasutades seda teadmist nii üksikute keelte kui ka keelestruktuuri üldiste tunnusjoonte kirjeldamiseks kas ajaloolises, sotsiaalses või keelevõime kontekstis. Akadeemilisel teadusel pole üldiselt olnud huvi tegelda argielu praktiliste probleemidega. Laialt levinud arusaama järgi peaks selliste probleemidega tegelema niinimetatud rakendusteadus, justkui oleks olemas kindel tööjaotus. Lingvistika puhul siis - rakenduslingvistika.

Rakenduslingvistika on päris hästi välja kujunenud distsipliin, ja seda mitte üksnes teiste rakendusteaduste taustal. Paljudes maailma ülikoolides õpetatakse rakenduslingvistikat kraadiõppe tasemel, olemas on rakenduslingvistika osakonnad ja õppetoolid, ilmub mitmeid ajakirju (nt Annual Review of Applied Linguistics, Applied Linguistics, Journal of Applied Linguistics, International Review of Applied Linguistics, Annual Review of Applied Linguistics, Zeitschrift für Angewandte Linguistik, kui nimetada mõnda) ja käsiraamatuid, nagu „The Oxford Handbook of Applied Linguistics” (Kaplan 2002), "The Blackwell Handbook of Applied Linguistics” (Davies, Elder 2004b), 9-köiteline Mouton de Gruyteri sari „Handbooks of Applied Linguistics" (HAL, ilmunud alates 2007. aastast) või Routledge'i aina täienev sari „The Routledge Handbooks in Applied Linguistics” (RHAL, ilmunud alates 2010. aastast). Peale selle on paljudes maades oma akadeemilised rakenduslingvistika ühingud, keda ühendab rahvusvaheline katusorganisatsioon Association Internationale de Linguistique Appliquée ehk AILA. AILA loodi peaaegu 50 aastat tagasi ja nüüd kuulub sinna umbes 40 rahvuslikku või piirkondlikku ühingut ühtekokku üle 7000 liikmega. AILA kongresse, kuhu tavaliselt koguneb üle 2000 teadlase, peetakse iga kolme aasta järel. 17. kongress toimub 2014. aastal Austraalias, Brisbane'is. Võib seega öelda, et rakenduslingvistika paistab seisvat kindlal jalal.

Lähemal vaatlusel on rakenduslingvistika kui iseseisva distsipliini staatus siiski mõnevõrra ähmasem. Viimasel ajal on ilmunud mitmeid ajakirju või kogumikke ja toimunud hulk üritusi, kus seda otsesõnu on arutatud, nt ajakirja International Journal of Applied Linguistics 1997. aasta köide, Seidl- 
hoferi raamat „Controversies in Applied Linguistics” (2003) või Ameerika rakenduslingvistika ühingu 2004. aasta konverentsil Robert Kaplani mälestuseks peetud rakenduslingvistika ulatust käsitlev kollokvium, samuti on selle üle arutlenud enamik juba mainitud käsiraamatute eessõnu. Need väljaanded ja üritused peegeldavad tõsiasja, et rakenduslingvistikat on algusest peale vaevanud eneseusu puudus, identiteedikriis ja tarve õigustada oma staatust - peamiselt puudutab see tema sõltuvust või sõltumatust teoreetilisest lingvistikast või teistest teoreetilistest valdkondadest. Vaid üks näide. Vaagides rakenduslingvistika üleilmset nähtavust akadeemilises maailmas, klassifitseerib William Grabe (2000) selle sõltumatuks kujunemisjärgus teadusharuks, Alan Davies ja Catherine Elder (2004a: 4 jj) avaldavad säärase väite üle kahtlust ja kinnitavad, et rakenduslingvistikat peaks pigem pidama praegu ja tulevikus - pelgalt uurimisvaldkonnaks, mis ühendab väga erinevaid teemasid ja huvisid.

Käesolevas artiklis püütakse arutleda rakenduslingvistika epistemoloogilise staatuse üle. Artikli põhiseisukoht on, et rakenduslingvistika pole kumbagi: ei iseseisev eriala ega ka lõdvalt seotud teemade ja huvide kogum. Pigem võiks rakenduslingvistikat pidada spetsiifiliseks lingvistikaks, nimelt „tegusaks lingvistikaks, mis lahendab probleeme”. Kõigepealt antakse lühike ajalooline ülevaade kõnealuse valdkonna arengust ja levikust üle maailma (ptk 1), seejärel käsitletakse mõningaid teooria ja praktika suhete epistemoloogilisi küsimusi nii üldiselt kui ka keeleteaduses (ptk 2), arutletakse kahe domineeriva vaatenurga üle, mis eitavad rakenduslingvistika sõltumatust teoreetilisest keeleteadusest (ptk 3 ja 4), vaadeldakse praktika osa teoreetiliste arengute käivitamisel (ptk 5), lõpuks väideldakse autonoomse teoreetilise baasiga rakenduslingvistika poolt, mida kontseptualiseeritakse kui valdkondadevahelist viisi uurida keelt praktilisel eesmärgil, s.t lahendades keele ja suhtluse praktilisi probleeme (ptk 6 ja 7).

\section{Valdkonna areng}

Rakenduslingvistika ajalooga tegelevad väljaanded paistavad olevat üksmeelel selles, et paigutavad rakenduslingvistika sünniaja aastasse 1948, mil ilmus ajakirja Language Learning esimene köide, alapealkirjaga A Quarterly Journal of Applied Linguistics. See oletus on siiski väär. Otto Back (1970) on osutanud, et rakenduslingvistika idee on Euroopas jälgitav juba XIX sajandi alguses ning et terminit rakenduslingvistika on kasutatud juba XX sajandi alguses. Keeleõppe ajakirja kuulutamine lähtekohaks seletab ehk, miks iseäranis ingliskeelses kirjanduses on rakenduslingvistikat seostatud esmajoones võõrkeele õpetamise ja õppimisega, eriti inglise keele kui võõrkeele õpetamisega.

Inglise keeleruumist väljapoole jäävates maades, aga aastate möödudes ka ingliskeelses maailmas endas, hakati terminit rakenduslingvistika tarvitama laiemalt. 1970. aastatest peale hakkas välja kujunema teise keele omandamise teooria, mis keskendus pigem õppimisele kui õpetamisele, samuti hakkasid tasapisi endale tähelepanu tõmbama keelekorraldus ja keelepoliitika. Lisaks neile koondusid lõpuks rakenduslingvistika alla peale psühho- ja neurolingvistika rakenduslike aspektide (s.t kõne- ja keelehäirete diagnoosimise 
ja ravi) veel keele kadu, kirjaoskus, mitmekeelsus, leksikograafia, korpuslingvistika, kirjalik ja suuline tõlkimine, keeletehnoloogia, keele ja ühiskonnaga seotud asjad (nt vähemusrahvuste õigused), keel ja sugupool, keel ja ajakirjandus, nagu ka vähem tuntud alad, näiteks keel ja ametialane karjäär, keel ja perekond, keel ja avalikud teenused, keel ja tervis, keel ja inimõigused, keel ja rahvusvaheline olukord, samuti ametisuhtlus ühes selliste aspektidega nagu erikeeled või teksti mõistetavus. Säärane rakenduslingvistika valdkonna laienemine on märk tema raskuskeskme nihkumisest keeleteaduselt mujale: psühholoogia, sotsioloogia, antropoloogia, politoloogia, kognitiivteadused ja infotehnoloogia saavad vähemalt sama oluliseks kui mitte olulisemaks rakenduslingvistika hüpoteeside, meetodite ja teooriate allikaks. Uuemaid sihtvaldkondi ja varem domineerinud võõrkeeleõpet ühendab keelele ja suhtlusele keskenduv fookus - paistab selgelt välja, et rakenduslingvistika haare on laienenud keeleõppe edendamiselt suhtluse edendamisele. Sellist arengut peegeldab ka AILA ajalugu. Esimesel AILA maailmakongressil (1964) oli üksnes kaks suunda: võõrkeele õpetamine ja masintõlge. Ent kui me vaatame 2011. aasta Pekingi maailmakonverentsi rakenduslingvistika sektsioonide nimekirja, on päevselge, kui haraliseks see valdkond on kasvanud:

1) esimese keele omandamine,

2) teise keele omandamine,

3) kirjalik ja visuaalne kirjaoskus,

4) psühholingvistika,

5) emakeeleõpe,

6) kirjakeeleõpe,

7) võõrkeele õpetamine ja õpetajakoolitus,

8) iseseisev keeleõpe,

9) keel ja haridus mitmekeelses ühiskonnas,

10) õppevahendid ja keeleõpe,

11) äri- ja ametisuhtlus,

12) tõlge, tõlkimine ja vahendamine,

13) keel ja õigus,

14) keelesituatsioon töökohas,

15) avalikkuse ja meedia keel,

16) sotsiolingvistika,

17) keelepoliitika,

18) mitmekeelsus ja mitmekultuurilisus,

19) kultuuridevaheline suhtlus,

20) rakenduslingvistika Aasias,

21) diskursuseanalüüs ja pragmaatika,

22) retoorika ja stilistika,

23) kontrastiivlingvistika ja vigade analüüs,

24) leksikograafia ja leksikoloogia,

25) diskursuse ja teksti multimodaalsus,

26) keeleoskuse hindamine ja testimine.

Juba esimesel pilgul on ilmne, et see loend esindab üsna juhuslikku kogumit ning et nimetatud suunad on üsna erineva mahuga. Näiteks keelepoliitika on ju selgelt sotsiolingvistika haru. On küllalt keeruline hoomata ühenda- 
vat printsiipi või ühiseid kriteeriume, mille alusel neid kõiki pidada rakenduslingvistilisteks valdkondadeks.

Pole kahtlust, et see nimekiri esindab pigem AILA liikmeks olevate ning end sedakaudu rakenduslingvistikaga sidunud teadlaste ajas muutuvaid huvisid, mitte rakenduslingvistika selgepiirilist sisu. Siiski ei peegelda see niivõrd AILA organisatsioonilise struktuuri puudujääke, kuivõrd rakenduslingvistika sildi alla koondunud teemade paljust.

Täpselt samasugust mitmekesisust võib täheldada ka ajakirjades ja käsiraamatutes, millest eespool juttu oli. Teiselt poolt võib selle nimekirja põhjal ikkagi järeldada - nagu juba öeldud -, et ingliskeelses maailmas domineerib siiani vaatenurk, mis võrdsustab rakenduslingvistika võõrkeele õpetamisega, kuna muude maade rakenduslingvistid kalduvad rohkem tegelema keelekasutuse üldiste sotsiaalsete protsessidega. Samasugune inglisemeelne kallak paistab välja ka käsiraamatutes, näiteks sarjas „Edinburgh Course in Applied Linguistics” (Allen, Corder 1973-1975; Allen, Davies 1977), millel pole alapealkirja „keeleõppes” - et viidata valdkonnale, mida seal tegelikult käsitletakse -, või värskemates väljaannetes, nagu „Encyclopedic Dictionary of Applied Linguistics” (Johnson, K., Johnson, H. 1998), mis ongi alapealkirjastatud kui „Keeleõppe käsiraamat” („A Handbook for Language Teaching”), ja Norbert Schmitti (2002) „An Introduction to Applied Linguistics”, mis samuti tegeleb kitsalt keeleõppe valdkonnaga. Seevastu Saksa rakenduslingvistika ajakiri Zeitschrift für Angewandte Linguistik või Mouton de Gruyteri käsiraamat „Handbooks of Applied Linguistics” (HAL) katavad kaugelt laiemat hulka valdkondi. Kokkuvõtteks, kontinentaalses Lääne-Euroopas, ja eriti Saksamaal, tuntakse palju suuremat huvi selliste teemade vastu nagu „keerulistes tingimustes toimuv suhtlus".

Austraalias keskendus rakenduslingvistika algul teiste keelte, mitte niivõrd inglise keele õpetamisele, samuti immigrantide keele õpetamisele (McNamara 2001). Keeleõpetamine, eriti inglise keele kui võõrkeele õpetamine, on rakenduslingvistika ülevaadetes ka muudes maailma paikades tavaliselt see tuum, mille ümber koonduvad muud rakenduslingvistilised tegevused - nii on see ka ajakirja AILA Review 17. köites („World Applied Linguistics”, 2004), mis oli pühendatud ühingu 40. aastapäevale.

Sinfree Makoni ja Ulrike Meinhoff (2004) kirjeldavad nimetatud köites, kuidas rakenduslingvistika (Sahara-taguses) Aafrikas on siiamaani rohkem või vähem piirdutud endiste kolonisaatorite keelte, peamiselt inglise keele õpetamisega. Esitledes prototüüpset Ladina-Ameerikat Brasiilia näitel, on Marilda Cavalcanti (2004) kirjeldanud Inglismaalt ja USA-st naasnud doktorantide algatatud tegevust, mis - vastavalt seal omandatud rakenduslingvistika mudelile - keskendus ikka esmalt inglise keele, seejärel muude keelte õpetamisele. Alles seejärel hakati tegelema (emakeele) kirjaoskuse, tõlkimise, keele ja sugupoole teemaga ning identiteedidiskursusega. Nagu enamikus Lääne maades, võib Brasiilia rakenduslingvistikat tänapäeval iseloomustada kui valdkondadevahelist ettevõtmist, mis asub lähemal sotsiaalteadustele kui lingvistikale. Nagu on kinnitanud Anne Pakir (2004), hõlmab ka Aasias inglise keele õpetamine ja selle keele roll regionaalse lingua franca'na peamise osa rakenduslingvistikaks peetavast alast, jättes väga vähe ruumi üksikutele muudele suundadele, näiteks keelepoliitikale ja keelekorraldusele. Nõnda ei ole sugugi üllatav, et AILA liikmeks olev Jaapani rakenduslingvistika 
ühing kuulub samal ajal Jaapani kõrgkooli inglise keele õpetajate ühingusse või et Hiinat esindab AILA-s Hiina inglise keele õpetajate ühing. Arvestades, kui suur hulk valdkondi ja uurimisteemasid mahub mujal rakenduslingvistika tiiva alla, näivad Aafrika ja Aasia mõneti muust maailmast maha jäävat. Siiski, pidades silmas spetsiifilisi keele- ja suhtlusprobleeme, millega inimesed neis maades põrkuvad, pole sugugi võimatu, et Aasia ja Aafrika rakenduslingvistika täieneb peagi uudsete uurimisalade ning teooriate ja meetoditega.

\section{Rakenduslingvistika teooria ja praktika}

Pangem tähele, et siinne arutlus rakenduslingvistika kui valdkonna staatuse üle ei keerle mitte niivõrd tema u urimis al a, kuivõrd u u rimisvi is i ümber, täpsemalt, teooria ja praktika suhte ümber, kus „teooria” tähistab esmajoones „lingvistilist teooriat”. See suhe puudutab ennekõike just rakenduslingvistika epistemoloogilist staatust, mis on olnud problemaatiline rakenduslingvistika algusaegadest peale. Järgnevalt vaadeldakse teoreetiliste ja rakenduslike teaduste vahekorda üldiselt, seejärel arutletakse eri lähenemisviiside üle rakenduslingvistikas, pidades kummagi puhul silmas teooria ja praktika vahekorda, aga ka rakenduslingvistika üldist ulatust.

Teooria ja praktika eristus läbib kogu läänemaailma teadusajalugu antiikaegadest peale. Algul peeti ainsaks akadeemiliseks ja teoreetiliseks valdkonnaks filosoofiat. Hiljem said selle staatuse ka muud juhtivad distsipliinid. Akadeemilise distsipliinina olid need kõik teoreetilised teadused. Akadeemilised erialad olid priid utilitaarsetest eesmärkidest, teooria sõltumatus kuulus olemuslikult nende juurde: ülikoolide ja akadeemiate hõlma alla koondununa ei sõltunud nad poliitikast ega religioonist. Meenutagem, kuidas meditsiin kui teadus pidi läänemaailmas läbima pika tee, et jõuda habemeajaja töötoast akadeemiasse.

See tõi kaasa kaugenemise argimuredest, mis väljendus (ja väljendub siiani) halvustavas suhtumises praktikasse ja praktikutesse. Sõna rakendus on juba iseenesest negatiivse konnotatsiooniga; see paistab veelgi ilmsem, kui mõelda sõna teoreetiline harjumuspärasele sünonüümile puhas, näiteks paaris puhas matemaatika ja rakendusmatemaatika. Puhta vastand on teatavasti ebapuhas, määrdunud - seeläbi kandub negatiivsuse vari ka valdkonnale, mis paigutub puhta ehk teoreetilise vastandiks.

Pikka aega valitses samasugune suhe ka lingvistika ja rakenduslingvistika vahel. Alles hiljaaegu oli rakenduslingvistika ala, mida ühelt poolt suunasid ümbritseva maailma praktilised asjad ja teiselt poolt nendelesamadele asjadele post hoc kohandatavad moodsad lingvistikateooriad ning mis ise - erinevalt lingvistikast - ei püstitanud uusi, teooria arengut mõjutavaid uurimisküsimusi. Võttes oma rakenduste lähtealuseks keeleteaduse kiiresti muutuvad teooriad, piiras rakenduslingvistika oma haarde pelgalt (keele) struktuuriga seotud teemadega, tõrjudes muid, näiteks psühholoogia, etnoloogia, sotsiaalantropoloogia või sotsioloogia vaatenurki.

Konrad Ehlich (1999) on selle põhjuseks pidanud tõsiasja, et kujunedes teoreetiliseks teaduseks, on lingvistika ise pidevalt piiranud oma objekti ulatust, asendades inimeste argikogemusega seotud keele ideaalse ja põhimõtteliselt ebareaalse entiteediga. Ehlichi meelest on seda põhjustanud järgmised 
isekehtestatud metodoloogilised piirangud, mis iseloomustavad moodsat lingvistikat:

1) Saussure hülgas vormikireva ja ebaühtlase keele (pr langage) kui lingvistika uurimisobjekti sobilikuma, homogeense langue'i kasuks („tervik iseendas"), järgides oma aja filosoofiateaduse metodoloogilisi printsiipe;

2) strukturalistid hülgasid tähenduse kui lingvistika uurimisobjekti taas meetodi pärast - vastavalt tol ajal valitsevale biheivioristlikule paradigmale, mille järgi tähendust ei saanud vaadelda, mistõttu see ei saanud olla teadusliku uurimise objekt;

3) Chomsky taandas lingvistika peamiseks uurimisobjektiks lause samuti metodoloogilisel põhjusel, nagu tema varastest töödest näha on („Syntactic Structures”, 1957, „Aspects of a Theory of Syntax”, 1965), nimelt et allutada keeleuurimine formaalsetele matemaatilistele mudelitele.

Ehlich on selgesti näidanud, et sellised metodoloogiliselt motiveeritud kitsendused teoreetilises lingvistikas viivad teooria eemaldumiseni tegelikkusest. Ehlich väidab, et just rakenduslingvistika peaks olema see varjupaik, mis mahutab oma rüppe ke ele mitmekesisuse ja komplekssuse, ning vabastama end niinimetatud „rajust” strukturaalsest või generatiivsest lingvistikast.

\section{Rakendatud lingvistika vs. rakenduslingvistika}

Pidagem neid lingvistikateooriate metodoloogilisi kitsendusi meeles, samuti nende poolt praktilistele eesmärkidele kehtestatud piiranguid, eeskätt seetõttu, et siiamaani näib laialt levinud arusaama rakenduslingvistika olemusest varjutavat lingvistikateooria teatav ühekülgne rakendus. Kõige aredamalt on väljendanud seda Pit Corder oma raamatus „Introducing Applied Linguistics”, kus ta ütleb: „Rakendada lingvistilist teadmist mõnele objektile on tegevus - või rakenduslingvistika -, nagu nimigi ütleb. See pole teoreetiline uurimus. See kasutab teoreetiliste uurimuste tulemusi. Rakenduslingvist on tarbija või kasutaja, mitte teooriate looja" (Corder 1973: 10).

Selle ettekirjutusliku tõdemuse on Henry Widdowson (1984) leidlikult sildistanud terminiga rakendatud lingvistika (pro rakenduslingvistika). Ehkki Corderi vaatenurgaga näivad nõustuvat paljud, vähemalt mis puudutab keele õpetamist, on jätkuvalt kahtluse all oletus, et lingvistikateooriad suudavad pakkuda mingit praktilise tähtsusega tuge. Sampsoni kommentaar on näiteks üsna poleemiline: „Ma ei usu, et lingvistikal on midagi panustada inglise keele või teiste Euroopa kirjakeelte õppesse. Paljud inimesed, kes seda väidavad, petavad minu meelest nii ennast kui teisi. See on tähtis just seetõttu, et nagu paljusid teisi kahtlasi ettevõtteid, rahastavad ka rakenduslingvistika tööstust väga suures ulatuses apla ja türanliku riigi haardes olevad abitud maksumaksjad, mitte need, kes näevad selles mingit väärtust (Sampson 1980: 11).

Tõele au andes tuleb tunnistada, et isegi teoreetilise keeleteaduse esindajad ise on tavaliselt üsna tagasihoidlikud ses suhtes, mis puudutab nende teooriate praktilist mõju. Siinkohal on kohane tsiteerida Noam Chomsky sõnavõttu 1966. aastal Northeasti võõrkeelte õpetamise konverentsil, kus ta väljendas umbusku lingvistika ja psühholoogia rolli suhtes keeleõppes, seades eelnevalt otsesõnu kahtluse alla keelepedagoogika tõsiseltvõetavuse: „Tõepoolest ei usu ma eriti, et keelte õpetamisel oleks midagi peale hakata 
nende tulemuste ja avastustega, mis lingvistikas ja psühholoogias on saavutatud" (Chomsky 1966: 152-153).

Kuid üsna pea lisab ta: „On väga võimalik, et psühholoogia ja lingvistika põhitõed ja uurimistulemused võivad pakkuda keeleõpetajale kasulikke teadmisi. Kuid seda tuleb alles tõestada, selles ei saa ette kindel olla. Keeleõpetaja ise peab pakutava omaks võtma või tagasi lükkama. Psühholoogias ja lingvistikas on vähe sellist, mida saab võtta hea usu peale" (Chomsky 1966: 155).

Chomsky ei räägi siin mitte oma keeleteooria rakendustest, vaid implikatsioonidest, andes mõista, et pole tema asi neid implikatsioone välja töötada. Teatavas mõttes ühtib see eespool mainitud Corderi (1973) rakendatud lingvistika kontseptsiooniga.

\section{Rakenduslingvist teooria ja praktika vahendajana}

On selge, et õpetajal kui lingvistikateooria lõpptarbijal võib käia üle jõu hinnata lingvistikateooria adekvaatsust oma praktiliste probleemide lahendamisel. Siinkohal tuleb rakenduslingvistikat mõtestada teisiti - mõiste abil, mida innukalt on propageerinud Henry Widdowson.

Paljudes oma publikatsioonides (nt Widdowson 2003: ptk 1) on ta väitnud, et ühelt poolt eristuvad lingvistika ja keeleõpetamistöö diskursused väga suurel määral, mistõttu võib õpetajal olla raske mõista teoreetikute motiive ja mõisteid. Teiselt poolt on ta rõhutanud, et enne kui rakendada teooriat praktilisele probleemile, tuleb kõigepealt tuvastada, kas teooria on käesoleva probleemi jaoks üldse kohane, mis omakorda eeldab, et argipäeva praktilised probleemid tuleb ümber sõnastada - või pigem, tõlkida - teooria keelde. Nii jõuabki ta järeldusele, et rakenduslingvisti missioon on olla vahendaja teooria ja praktika vahel. Widdowsoni erinevad seletused rakenduslingvistika mõiste kohta võib kokku võtta järgmiselt:

- rakenduslingvistika on vahendusprotsess, mis uurib, kuidas teoreetilisi seisukohti tõlgendada nii, et nad sobituksid praktiliste eesmärkide, eriti võõrkeele õpetamisega;

- rakenduslingvistika teeb keeleteaduse aktuaalseks, s.t ta tõlgendab üksnes lingvistika vaatenurki ja teooriaid ning hoidub turvalisse kaugusse interdistsiplinaarsetest lähenemistest keeleõppele. Rakenduslingvist ei pea näiteks sotsioloogiliste ja psühholoogiliste leidustega keele ja keelekasutuse kohta kursis olema seetõttu, et ta saabki ekspert olla ainult lingvistikas ja nii on see, mida ta ütleb, igal juhul kallutatud ja visandlik;

- vahendamine ise peab igatahes olema kriitiline, sisaldama läbikaalutud järeldusi ning ideede kehtivuse läbiproovimist.

Widdowson ei ütle selgelt, mida ta peab pärislingvistika subjektiks, kõrvutades seda keele interdistsiplinaarse uurimisega. Jääb ka ebaselgeks, mil määral ta lingvistikakontseptsioon piirneb strukturaalsete ja generatiivsete teooriatega, millest eespool juttu oli, ehkki ta kaudselt möönab (nt Widdowson 2003: 14), et lingvistika ise hõlmab suure hulga interdistsiplinaarseid uuringuid. Siin tuleb esitada mõned kriitilised kommentaarid.

Esiteks, rakenduslingvisti sellist ebamugavat positsiooni võib piltlikustada võileiva-metafoori abil: akadeemiline rakenduslingvist on nagu kokkupres- 
situd täidis kahe viilu vahel, millest üks, ülemine, on teoreetiline lingvist ja teine, alumine, on praktik (või kui soovite, vastupidi, praktik ülal ja teoreetik all), kusjuures surve on mõlemapoolne. Võib juhtuda, et teoreetikule tundub, et rakenduslingvist lahjendab tema teooriat seeläbi, et kasutab seda eri kontekstis, või et praktik leiab, et rakenduslingvisti tõlgendused on siiski liiga omaette ja kauged tema igapäevastest vajadustest. Suur osa õpetajakoolitusest põhineb eeldusel - või lausa müüdil -, et tulevaste õpetajate akadeemiline koolitus võimaldab neil hiljem oma tegevust teoreetiliselt kirjeldada ning et kool varustab neid teadmiste ja oskustega kasutada rakenduslingvisti tõlgendusi oma igapäevaprobleemide lahendamiseks. Meie kogemus näitab, et üldjuhul see nii pole. Õpetajad soovivad enamat: mitte üksnes seda, et teooria praktilisest tulust räägitakse, vaid et seda ka otseselt demonstreeritaks nad kalduvad eelistama käepäraseid puust-ja-punaseks lahendusi. Seega võib rakenduslingvistika nii ülikooli teoreetikute kui ka õpetavate praktikute jaoks olla pelk vahendamise protsess, seejuures üsna ebakonkreetne.

Teiseks, kõigis keeleteaduse valdkondades, isegi tuumvaldkondades (nt fonoloogia, morfoloogia, süntaks ja semantika), on uuringud heterogeensed ja kohati väga rafineeritud. Seetõttu on väga raske kõigi uuemate uurimistulemustega kursis olla ja hinnata nende sobivust teatavaks praktiliseks ülesandeks mõlemat pidi, nii teoreetiliselt kui ka metodoloogiliselt.

Kolmandaks, ja see on kõige tähtsam, Widdowsoni lähenemine mõistab rakenduslingvistika vahendama pärislingvistika olemasolevaid teooriaid ja meetodeid, arvestamata, et praktiliste asjade jaoks võib vaja minna uusi teoreetilisi vaatenurki või meetodeid. Sarnaselt Corderiga (1973) rakendab Widdowsoni kontseptsioon lingvistikat üksnes post hoc. Samas on paljud teaduslikud uuendused alguse saanud praktilistest probleemidest, ja see käib ka keeleteaduse kohta.

\section{Enne praktika, siis teooria}

Võtkem näiteks korpuslingvistika, mis on loonud radikaalselt omanäolise vaate keelele kui tervikule. See saab iseäranis selgeks John Sinclairi töödes, mis on seotud COBUILD-i korpusega. Michael McCarthy (2001: 127) meelest esindavad Sinclairi tööd (nt tema raamat „Corpus, Concordance, Collocation”, 1991) klassikalist sõltumatut rakenduslingvistikat ses mõttes, et ta jõuab praktika põhjal uute järeldusteni, mitte vastupidi. Olles hõivatud õppesõnaraamatu koostamise väga praktiliste ülesannetega, jõuab Sinclair üha selgemale äratundmisele, et mitmed keeleteaduse enesestmõistetavad põhitõed, nagu süntaksi primaarsus või sõnavara ennustamatus ja ebareeglipärasus, korpuse andmete najal lihtsalt enam ei kehti. Ilmnes, et sõnavara on palju regulaarsem: korpuses tulid igal pool esile mitmesugused reeglipärased sõnakasutusmallid. Idioomid ei ole erand, vaid lausa reegel, mistõttu nad on tähenduse moodustamises vähemalt sama tähtsad kui süntaks. Need ja teised avastused sundisid Sinclairi järeldama, et tähenduse ja struktuuri vahel on tihe side ning et väga sageli hoiavad teksti koos - lisaks kollokatsioonidele ja püsiühenditele - just mitmesugused sõnakombinatsioonid, mis moodustavad lauserümpasid või poolfabrikaadist ühendeid. Sinclairi jaoks on süntaks pigem hädaabivahend, et tagada sujuvat väljendust. 
Sinclair seab kahtluse alla paljud traditsioonilise lingvistika teooriad, ja mõistagi ei jaga tema seisukohti kõik lingvistid. Siiski on korpuseanalüüsist nüüdseks saanud lausa peavoolu meetod ja see on olulisel kohal uutes lingvistikateooriates, nagu kasutuspõhine keeleomandamine (nt Tomasello 2003) või konstruktsioonigrammatika (nt Gries, Stefanowitch 2006; Goldberg 2006). Seega näitab Sinclairi juhtum, et praktiline probleem - tema puhul sõnaraamatu koostamine - võib mõjutada teooriat.

On ka teisi näiteid, kuidas argielust uue teooriani on jõutud. Üks sääraseid on suhtluse sotsiolingvistika (interactional sociolinguistics), eriti John Gumperzi (1982) kontekstualisatsiooniteooria. ${ }^{1}$ Teooria käivitajaks olid taas praktilised probleemid. 1970. aastatel töötas Gumperz Inglismaal Southallis tööstuse keelekoolituskeskuses (National Centre for Industrial Language Training, NCILT), kus ta pidi uurima, miks Aasia immigrantide ja brittide vahelises suhtluses tekkis ühtelugu arusaamatusi vähemusrühma kahjuks, vahel isegi diskrimineerimist, ning välja mõtlema ja koostama koolitusmaterjale, mis aitaksid neist probleemidest üle saada. Gumperz ja ta kolleegid lindistasid ja analüüsisid rühma omavahelist suhtlust, rakendades kultuurispetsiifilist vestlusanalüüsi, kõneaktide teooriat ja Grice’i pragmaatikaprintsiipe. Selleks et suhtlejate probleeme ja vastastikust mittemõistmist vaadeldud andmete toel põhjendada, tuli välja arendada uued mõisted, nagu kultuurispetsiifiline suhtlus, ning visandada uued suhtlusmudelid, mis toetuvad suhtlejate kontekstivihjetele (contextualisation cues), s.t verbaalsetele, paraverbaalsetele ja mitteverbaalsetele väljendusvahenditele, mille abil edastatakse üksteisele käimasoleva vestluse tõlgendusnüansse. Niisiis, ka sel juhul andsid praktilised probleemid tõuke nii praktilisteks kui ka teoreetilisteks järeldusteks: Gumperz ja ta kolleegid töötasid välja koolitusmaterjale (sh populaarse BBC sarja „Crosstalk”, vt Gumperz jt 1979) ning rajasid kogunisti uue uurimisparadigma.

Samamoodi, ilma rakenduslingvisti vahendava tegevuseta on praktikast lingvistilise teooriani jõutud funktsionaalses pragmaatikas (Ehlich 1999; Brünner, Graefen 1994). See teooria tõukus reduktsionistlikust kriitikast, mis käsitles pragmaatikat kui kõigi nende probleemide prügikasti, mida süntaks ja semantika kirjeldada ei suuda. Seeasemel väidab teooria, et pragmaatika peab olema empiiriline ses mõttes, et ta analüüsib autentset suulist suhtlust eesmärgiga rekonstrueerida tegevused, mida suhtlevad inimesed sooritavad, ning tuvastada funktsioonid, mis neil keelelistel tegevustel võivad olla. Teooriat on tugevasti mõjutanud filosoofiline tegevusteooria (action theory), mistõttu huvikeskmes on tegevusmallid, mida situatsiooni- või tööalane suhtluskontekst rohkem või vähem ette kirjutab. Et tuvastada tegevusmallid, millele tugineb mingi suhtlusfunktsioon ja keeleline tegevus institutsionaalses või tööalases suhtluses, analüüsiti õpetaja ja õpilase, arsti ja patsiendi, kliendi ja ametiisiku suhtlust avalikus ruumis jm. Ja sellest, mis algul oli lihtsalt teoreetiline katse ületada lingvistide reduktsionistlikku keelevaadet, kasvas kõneleja eesmärkide ja suulise suhtluse vaatlusel välja täiesti praktiline asi: samad teadlased, kes kirjeldasid töö- ja ametisuhtlust, töötasid välja õpetajate, arstide, ametnike jt suhtluspädevust arendavad koolitusprogrammid üldnimetuse all rakenduslik vestlusanalü̈̈s (sks angewandte Gesprächsforschung).

1 Eestis on kasutatud terminit suhtluskäitumine (Pajusalu jt 2010), ka sotsiolingvistiline käitumine ja pragmaatilis-konversatsiooniline uurimissuund (nt Praakli 2009) - tõlkija märkus. Vt ka Tiit Hennoste artiklit siinses numbris lk 674-695. 


\section{Rakenduslingvistika iseseisvus}

Pole kahtlust, et kõik need kaasused kuuluvad rakenduslingvistika alla. Ja sellisena iseloomustavad nad rakenduslingvistika epistemoloogilise staatuse eri tahke.

Esiteks, kõigis toodud näidetes sõlmivad sideme teooria ja praktika vahel ühed ja samad inimesed: kui nad tegelevad teooria ja meetodiga, siis võib neid nimetada teoreetikuteks, aga kui nad koostavad sõnaraamatut või kavandavad ja viivad läbi suhtlustreeningut, siis on nad praktikud. See tähendab, et vahemehi pole, samas on veider väita, nagu poleks siin rakenduslingvistikaga pistmist.

Teiseks, teooria ja praktika seos pole alati ühesuunaline liikumine teooriast praktikasse. Teooriat võib toita, isegi tingida praktika, nagu nägime korpuslingvistika ja suhtluse sotsiolingvistika puhul, aga samahästi võib teooria olla lähtekoht ja praktika selle katselava, nagu toimus funktsionaalse pragmaatika puhul. Seega võib järeldada, et rakenduslingvistika võib käivituda mitmel viisil. Ühelt poolt võivad seda ärgitada uudsed nähtused reaalses maailmas, nagu automaatne keeletöötlus või uue meedia keelekasutus. Rakenduslingvist, kes nendega tegelda püüab, võib katsetada juba olemasolevat lingvistilist meetodit või arendada uut, kui see vajalikuks osutub. Teiselt poolt võib keeleteaduses endas ette tulla konkreetseid küsimusi, mis vajavad lahendust - kas päris esimest korda või mingi teise nurga alt.

Kolmandaks, kui praktiline töö annab tagasisidet, mille tulemusel muudetakse või parandatakse teooriat ja meetodit, ning teooria annab omakorda tagasisidet praktikasse, hägustub nendevaheline piir. Vähemalt siinsete näidete järgi ei ole mingit mõtet piirata rakenduslingvistikat vaid ühega neist valdkondadest.

Neljandaks, kuigi siinsed näited on seotud praktikaga, on samas vallas ka teooriaid ja meetodeid, mis toimivad ilma säärase sidemeta - korpuslingvistikat, suhtluse sotsiolingvistikat ja funktsionaalset pragmaatikat saab pidada ka iseseisvateks teoreetilisteks suundadeks, lausa peavooluks, ning selles raamistikus tehtud uurimused on pädevad ka ilma praktilist ülesannet täitmata (nt ilma sõnaraamatut koostamata või suhtlust edendamata). Pole veel selge, kas käsitleda sellist lähenemist teoreetilise või rakenduslingvistika haruna.

Viiendaks, pangem tähele, et siinsed näited esindavad rakenduslingvistika valdkondi, mis ei ole seotud ei teise keele omandamise ega võorrkeele õpetamisega. See just iseloomustabki rakenduslingvistika viimase aja tüüpilist arengut: võib täheldada nihet keeleõppest ja lingvistikast (kui rakendatavate teooriate kogumist) keele kui kompleksse suhtlusvahendi poole - mis eespool on esitatud Ehlichi (1999) sõnastuses - ning sedakaudu üldisemate sotsiaalsete nähtuste ja protsesside suunas.

\section{Rakenduslingvistika kui probleemide lahendamine}

Äsjaesitatud argumentidest veelgi kaalukamaks osutub see, et on keelevaldkondi, kus ei ole võimalik eristada lingvistikat, rakenduslingvistikat ja praktikat. See paistab kehtivat eriti selliste alade kohta, mis toetuvad keele laiemale, kommunikatiivsele ja sotsiaalsele aspektile. Kuidas sel juhul rakendus- 
lingvistikat määratleda ning eristada teda pärislingvistikast ja praktikast?

Tundub mõistlik lähtuda teadusfilosoofias väljatöötatud üldisest rakendusteaduse mõistest. Karl Popperi järgi peaks iga akadeemiline distsipliin endalt küsima, mida tal on välja pakkuda, et lahendada individuaalseid, isikutevahelisi, sotsiaalseid, kultuuridevahelisi, poliitilisi või tehnilisi probleeme. See küsimus on rakenduslingvistika jaoks muidugi ülimalt asjakohane. Rakenduslingvistika vastus oleks: rakenduslingvistika ongi probleemide lahendamine, või täpsemalt, individuaalsete ja ühiskondlike keele ja suhtlusega seotud probleemide lahendamine.

Seda sisu kajastab Christopher Brumfiti (1995: 125) sõnastatud paljukorratud definitsioon: „[Rakenduslingvistika] on reaalelu selliste probleemide teoreetiline ja empiiriline uurimine, kus keel on kesksel kohal.”

Arvesse võttes, kuidas strukturalistid ja generativistid on keele mõistet moodsas keeleteaduses ahendanud, tuleks see definitsioon ümber sõnastada, et hõlmata laiemat, siinkirjeldatud sisu. Samuti tuleb täheldada, et kuigi probleemide lahendamine on mis tahes rakendusteaduse lõppeesmärk, tuleb selle saavutamiseks teha mõningaid eeltöid, lisaks on paljudel juhtudel lõpplahendus rohkem ühiskonna või muu võimumehhanismi kui üksiku rakenduslingvisti asi. Sel taustal võiks mõistlik rakenduslingvistika definitsioon kõlada nii:

Rakenduslingvistika on valdkond, mis kasutab ja vajaduse korral arendab lingvistika teooriaid ja meetodeid, et tuvastada, kirjeldada ja võimaluse korral lahendada reaalelu individuaalseid ja ühiskondlikke keele ja suhtlusega seotud probleeme.

Selle definitsiooni järgi on rakenduslingvistika sisu „teha lingvistikat”, keskendudes probleemide lahendamisele. See, mis teda kannustab, on teadmishimu (sks Erkenntnisinteresse). Huvi võib olla ka kriitiline, nagu on osutanud Chris Candlin (1990), ja peegeldada rakenduslingvistika mõju ühiskonna keeleprobleemidele, näiteks seoses rahvusvähemuse staatuse ja sotsiaalse seisundiga. Neil juhtudel, mil teooria ja rakenduse piir on ähmane, võimaldab mingit keelega seotud uurimust, projekti või muud tööd liigitada rakenduslingvistikaks selgelt praktilist lahendust otsiva hoiaku olemasolu.

Sellesama probleemide lahendamisele häälestatud teadmishimu toel on täiesti võimalik aktsepteerida AILA maailmakongressi teemaloendisse kuuluvaid, sisu ja ulatuse poolest väga ebavõrdseid valdkondi: niivõrd, kui näiteks diskursuseanalüüsi ja pragmaatika või psühholingvistika sfääri kuuluva tegevuse eesmärk on lahendada teatavaid keele ja suhtlusega seotud individuaalseid ja ühiskondlikke probleeme ning sealjuures midagi ka saavutatakse, sedavõrd võime rakenduslingvistika alana aktsepteerida ka suuri ja ebamääraste piiridega lingvistika valdkondi. 


\section{Kirjandus}

A 11 e n, John P. B., C o r d e r, S. Pit 1973-1975. The Edinburgh Course in Applied Linguistics. Kd 1-3. London: Oxford University Press.

Alle n, John P. B., D a vi es, Alan 1977. The Edinburgh Course in Applied Linguistics. Kd 4. London: Oxford University Press.

B a ck, Otto 1970. Was bedeutet und was bezeichnet der Begriff 'angewandte Sprachwissenschaft'? - Die Sprache, nr 16, lk 21-53.

Brumfit, Christopher 1995. Educational Linguistics, Applied Linguistics and the Study of Language Practices. Paper presented at the Annual Meeting of the British Association of Applied Linguistics (BAAL), Southampton.

B r ü n n e r, Gisela, G r a e f e n, Gabriele (toim) 1994. Texte und Diskurse. Methoden und Forschungsergebnisse der Funktionalen Pragmatik. Opladen: Westdeutscher Verlag.

C and lin, Chris 1990. What happens if Applied Linguistics goes critical? M. A. K. Halliday, J. Gibbons, H. Nicholas (toim), Learning, Keeping and Using Language. Kd 2. Amsterdam: John Benjamins, lk 461-486.

C a va l c a n ti, Marilda C. 2004. Applied Linguistics: Brazilian perspectives. AILA Review, kd 17, lk 23-30.

C h o m s ky, Noam 1957. Syntactic Structures. The Hague: Mouton.

C h o m s ky, Noam 1965. Aspects of a Theory of Syntax. Cambridge-Massachusetts: MIT-Press.

C h o m s ky, Noam 1966. Linguistic theory. - R. G. Mead, Jr. (toim), Language Teaching: Broader Contexts. Middlebury, VT: Northeast Conference on the Teaching of Foreign Languages.

C o r d e r, S. Pit 1973. Introducing Applied Linguistics. Harmondsworth: Penguin.

Davies, Alan, Elder, Catherine 2004a. General Introduction. - Applied Linguistics: Subject to discipline? - A. Davies, C. Elder (toim), The Handbook of Applied Linguistics. London: Blackwell, lk 1-15.

D a vies, Alan, E ld e r, Catherine (toim) 2004b. The Handbook of Applied Linguistics. London: Blackwell.

E h li c h, Konrad 1999. Vom Nutzen der Funktionalen Pragmatik für die Angewandte Linguistik. - M. Becker-Mrotzek, C. Doppler (toim), Medium Sprache im Beruf. Eine Aufgabe für die Linguistik. Tübingen: Narr, lk 23-36.

G o l d b e r g, Adele 2006. Constructions at Work: The Nature of Generalization in Language. Oxford: Oxford University Press.

Gra b e, William (toim) 2000. Applied Linguistics as an emerging discipline. Annual Review of Applied Linguistics, nr 2.

Grie s, Stefan Th., S t e f a n o w it s c h, Anatol (toim) 2006. Corpora in Cognitive Linguistics: Corpus-based Approaches to Syntax and Lexis. Berlin: Mouton de Gruyter.

G u m p e r z, John J. 1982. Discourse Strategies. Studies in Interactional Sociolingustics. Cambridge: Cambridge University Press.

G u m p e r z, John J., J u p p, Tom, R o bert s, Celia 1979. Crosstalk. A Study of Cross-Cultural Communication. Background Material and Notes to Accompany the B.B.C. Film. Southall, Middx: NCILT.

$\mathrm{HAL}=\mathrm{Kn}$ a p p, Karlfried, A n to s, Gerd (toim) 2007-. Handbooks of Applied Linguistics. Kd 1. Communicative Competence of the Individual; kd 2. Interpersonal Communication; kd 3. Communication in the Professions; kd 4. Com- 
munication in the Public Sphere; kd 5. Foreign Language Communication, kd 6. Multilingual Communication; kd 7. Intercultural Communication, kd 8. Technical Communication; kd 9. Language and Communication: Diversity and Change. Berlin-New York: Mouton de Gruyter.

Johnson, Keith, Johnson, Helen (toim) 1998. Encyclopedic Dictionary of Applied Linguistics: A Handbook for Language Teaching. Oxford: Blackwell.

K a pl a n, Robert B. (toim) 2002. The Oxford Handbook of Applied Linguistics. Oxford: Oxford University Press.

M a k o n i, Sinfree, M e i n h off, Ulrike H. 2004. Western perspectives in applied linguistics in Africa. - AILA Review, kd 17, lk 77-104.

M c Carthy, Michael 2001. Issues in Applied Linguistics. Cambridge: Cambridge University Press.

M c N a m a r a, Tim 2001. The Roots of Applied Linguistics in Australia. - Australian Review of Applied Linguistics, kd 24, nr 1, lk 13-29.

Paju s a l u, Renate, Vihm an, Virve, Kla as, Birute, Pajus a lu, Karl 2010. Eestlaste ja venelaste suhtluskäitumine: sina, teie ja keegi veel. - Eesti Rakenduslingvistika Ühingu aastaraamat, nr 6. Tallinn: Eesti Keele Sihtasutus, lk 207-224.

P r a a k li, Kristiina 2009. Esimese põlvkonna Soome eestlaste kakskeelne keelekasutus ja koodikopeerimine. (Dissertationes philologiae estonicae universitatis Tartuensis 24.) Tartu: Tartu Ülikooli Kirjastus.

P akir, Anne 2004. Applied Linguistics in Asia: Pathways, patterns and predictions. - AILA Review, kd 17, lk 69-76.

RHAL $=$ The Routledge Handbooks in Applied Linguistics 2010-. Köited: The Routledge Handbook of Forensic Linguistics; The Routledge Handbook of Corpus Linguistics; The Routledge Handbook of World Englishes; The Routledge Handbook of Applied Linguistics; The Routledge Handbook of Second Language Acquisition; The Routledge Handbook of Discourse Analysis; The Routledge Handbook of Language and Intercultural Communication; The Routledge Handbook of Language and Intercultural Communication; The Routledge Handbook of Multilingualism. Routledge.

S a m p s o n, Geoffrey 1980. Schools of Linguistics. Competition and Evolution. London: Hutchinson.

S c h m it t, Norbert (toim) 2002. An Introduction to Applied Linguistics. London: Arnold.

S e i d 1 h o f e r, Barbara (toim) 2003. Controversies in Applied Linguistics. Oxford: Oxford University Press.

S in cl a ir, John McH. 1991. Corpus, Concordance, Collocation. Oxford: Oxford University Press.

To m a s e 11 o, Michael 2003. Constructing a Language: A Usage-based Theory of Language Acquisition. Cambridge, MA: Harvard University Press.

Widdows o n, Henry G. 1984. Explorations in Applied Linguistic 2. Oxford: Oxford University Press.

Wi d d ow s o n, Henry G. 2003. Defining Issues in English Language Teaching. Oxford: Oxford University Press. 


\section{On the Epistemological Status of Applied Linguistics}

Keywords: applied linguistics, theoretical linguistics, language, communication

As a result of today's political and economic pressures, academic disciplines can no longer distance themselves entirely from the mundane practical problems of the societies that aliment them. They even cannot restrict themselves to just describing or interpreting those problems. Nowadays, all academic disciplines are increasingly required to justify the resources allocated to them and to shift their focus from problem understanding to problem solving.

This paper discusses the epistemological status of Applied Linguistics. It will argue in favour of the position that Applied Linguistics is neither an autonomous discipline nor a loosely connected set of issues and interests. Rather, it will be argued here that Applied Linguistics is a particular, focused way of „doing linguistics”, namely: „linguistics as problem solving”. To develop this argument, the presentation will, firstly, give a brief historical survey of the development of the field designated as "Applied Linguistics" and its spread around the world (Section 1), secondly, present some aspects of the relation between theory and practice both in epistemology in general and in linguistics (Section 2), discuss two influential positions that deny any independence of Applied Linguistics of Theoretical Linguistics (Sections 3 and 4), present examples for praxis as a trigger of theoretical developments (Section 5) and ultimately give arguments for a theoretically autonomous Applied Linguistics, conceptualized as an interdisciplinary way of doing linguistics with a practical purpose, i.e. with solving practical problems with language and communication (Sections 6 and 7).

Karlfried Knapp (b. 1946), PhD, Prof. Emeritus in English and in Applied Linguistics at Erfurt University, Ed.-in-Chief of the series „Handbooks of Applied Linguistics" and of European Journal of Applied Linguistics, founder of the European network of Applied Linguistics AILA Europe (2006), karlfried.knapp@uni-erfurt.de 